\title{
C1-C4 Dorsal Column Stimulation for Refractory Occipital Neuralgia Treatment. Case Report
}

\section{Estimulação da coluna dorsal em C1-C4 para tratamento de neuralgia occipital refratária. Relato de caso}

\author{
José Augusto Malheiros ${ }^{1,2}$ Sergio Augusto Vieira Cancado ${ }^{1}$ Célia Maria de Oliveira ${ }^{3}$ \\ Wancler Albert Gomes dos Santos ${ }^{1}$ \\ ${ }^{1}$ Division of Neurosurgery, Hospital Felício Rocho, Belo Horizonte/ \\ MG, Brazil \\ 2 Division of Neurosurgery, Hospital Luxemburgo, Belo Horizonte/MG, \\ Brazil \\ Address for correspondence Sergio Augusto Vieira Cancado, MD, \\ MSc, Divisão de Neurocirurgia, Hospital Felício Rocho, Avenida do \\ Contorno 9530 - Prado, 30110-017, Belo Horizonte/MG, Brazil \\ (e-mail: sergiomed124@gmail.com; sergiomed124@yahoo.com.br).
}

${ }^{3}$ Division of Nursing, Hospital das Clínicas, Universidade Federal de Minas Gerais (UFMG), Belo Horizonte/MG, Brazil

Arq Bras Neurocir 2017;36:200-202.

\begin{abstract}
Keywords

- occipital neuralgia

- neurostimulation

- spinal cord stimulation

- case report
\end{abstract}

\section{Resumo}

Introduction Refractory occipital neuralgia is a difficult medical condition, especially when the patient has already been submitted to occipital nerve neurectomy and radiofrequency rhizotomy. There is no case report of spinal cord stimulation in the C1C4 cervical segments for this condition.

Objective To evaluate if $\mathrm{C} 1-\mathrm{C} 4$ dorsal spinal cord stimulation is effective in a patient with refractory occipital neuralgia who was already submitted to neurectomy and rhizotomy.

Methods After obtaining the approval from the Ethics Committee of one of our institutions, a unilateral laminectomy was performed between C3 and C4, and a neurostimulator lead was conducted until the posterior portion of the $\mathrm{C} 1$ arc was in full view. Then we performed an intraoperative test to evaluate the correspondence between pain location and stimulation-induced paresthesias. We could not put the subcutaneous lead for such condition because of the scar tissue of the area and the previous neurectomy.

Results After one year of follow up, we noticed a dramatic improvement in pain control, as well as medication withdrawal. The score of the visual analogue scale was 9 before the surgery, and it dropped to 2 after 1 year of follow-up.

Conclusion Spinal cord stimulation between the $\mathrm{C} 1$ and $\mathrm{C} 4$ cervical segments can be an option for selected cases of refractory occipital neuralgia, including those patients who have already been submitted to neurectomy or rhizotomy.

Neuralgia occipital refratária é uma condição médica difícil, especialmente em pacientes submetidos previamente a neurectomia nos nervos occipitais e rizotomia por radiofrequência. Não há na literatura relato de estimulação da medula espinhal entre os níveis C1 e C4 para essa condição. received

February 1, 2017

accepted

May 31, 2017

published online

July 6, 2017
DOI https://doi.org/

$10.1055 / \mathrm{s}-0037-1604177$.

ISSN 0103-5355.
Copyright (e 2017 by Thieme Revinter

Publicações Ltda, Rio de Janeiro, Brazil
License terms

(c) $(1) \$$ 


\section{Palavras-Chave \\ - neuralgia occipital \\ - neuroestimulação \\ - estimulação da medula espinhal \\ - relato de caso}

Objetivos Avaliar se a estimulação da coluna dorsal da medula nos níveis C1 a C4 é eficaz no controle da dor em paciente com neuralgia occipital refratária já submetido a neurectomia e rizotomia.

Métodos Após aprovação do Conselho de Ética de uma de nossas instituições, foi realizada laminectomia unilateral de C3 e C4, com posterior introdução do conjunto de eletrodos em placa, que foi posicionado até que a porção anterior do arco de C1 estivesse sob visão direta. Posteriormente, foi realizado um teste intraoperatório para avaliar a correspondência entre a área dolorosa e a parestesia induzida pela estimulação. Não possível optar pelo uso de eletrodo subcutâneo devido ao extenso tecido cicatricial secundário às cirurgias prévias.

Resultados Melhora significativa da dor ocorreu ao longo de um ano de acompanhamento, com redução progressiva da dose da medicação. O valor da escala visual analógica no pré-operatório era 9, e após 1 ano de acompanhamento, reduziu para 2. Conclusão Estimulação da coluna dorsal da medula espinhal entre os seguimentos C1 e C4 pode, em casos selecionados, ser uma opção terapêutica na neuralgia occipital refratária, incluindo pacientes que já foram submetidos a neurectomia e rizotomia.

\section{Introduction}

Refractory occipital neuralgia is a difficult medical condition, especially when the patient has already been submitted to occipital nerve neurectomy and radiofrequency rhizotomy. There is no case report of spinal cord stimulation in the C1-C4 cervical segments for this condition.

\section{Presentation}

The patient (SCTA) was a 42-year-old female with a medical report of 2 years of refractory pain in the occipital region. She was submitted to anesthetic and corticoid blocks, and experienced partial resolution for months. The surgical approach for neurectomy of the major and minor occipital nerves was performed, and the patient showed no improvement after 3 months; instead, she experienced recurrence, worsening of the pain and refractoriness of the drugs (pregabalin $600 \mathrm{mg} /$ day plus duloxetine $60 \mathrm{mg}$ /day plus methadone $20 \mathrm{mg} /$ day). During this period, she was referred to our service. The proposed initial treatment was pulsed radiofrequency in the C2 ganglion and C3 root. We achieved a reduction of 30\% in the score of the visual analogue scale (VAS) after two attempts with no medication withdrawn. As there was a large portion of scar tissue in the occipital region, the introduction of a C1-C4 spinal cord neurostimulator by laminectomy was proposed.

\section{Technical Note}

The patient was under general anesthesia, in the prone position, with the head on a 3-pin holder. We performed unilateral exposure of the laminas of $\mathrm{C} 1$ until $\mathrm{C} 4$, and a small C4 laminectomy for the placement of the neurostimulator lead under the laminas of $\mathrm{C} 2, \mathrm{C} 3$ and $\mathrm{C} 4$ until the lateral portion of $\mathrm{C} 1$. We had to expose the $\mathrm{C} 1$ posterior arc and epidural space in order to guide the lead, and we checked the radioscopy to make sure the 16 -electrode surgical lead (Medtronic, Inc. Minneapolis, MN, US) was properly placed
(-Fig. 1). We turned the patient and performed an intraoperative awake test with an external trialing neurostimulator (Medtronic, Inc. Minneapolis, USA) to evaluate the covering pain area. Once we matched the area of pain with the neurostimulation, we connected the system and placed the neurostimulator's battery into the abdominal wall.

\section{Results}

There was an important improvement in pain with a significant reduction in the use of pain medication progressively. After 12 months of implantation, the visual analogue scale score was 2 , and the patient successfully achieved methadone and pregabalin withdrawal. The patient is currently using only duloxetine $60 \mathrm{mg} /$ day (-Fig. 2).

\section{Discussion}

Occipital neuralgia is often controlled with muscle relaxants, physical therapy, and anesthetic blocks with corticosteroids. In refractory cases, the intervention option is necessary. ${ }^{1}$ Currently, the most recommended interventions are performed with botulin toxin ${ }^{2}$ or pulsed radiofrequency. ${ }^{3}$ If refractoriness occurs, performing a neurectomy or a gangliectomy ${ }^{4}$ are options with controversial results, because they can worsen the painful condition. ${ }^{1}$ In this case, the patient had already taken anesthetic blocks with corticosteroids, with improvement only while the effect of the anesthetic lasted. The patient underwent an open surgery for neurectomy, but she showed no improvement after 3 months. Pulsed radiofrequency was then attempted twice, with the condition showing little improvement. The option for spinal cord stimulation instead of peripheral nerve stimulation ${ }^{4,5}$ was made because of the large portion of scar tissue in the occipital region and the medical report of neurectomy of the occipital nerves. In this case, we could not introduce the lead under the $\mathrm{C} 1$ arc (perhaps because of the previous manipulation), and we had to expose the $\mathrm{C} 1$ posterior arc and the epidural space to place the 16-electrode surgical lead under $\mathrm{C}$. 



Fig. 1 Dorsal cord stimulation for occipital neuralgia. (A) Preoperative photograph of the patient. Note the scar from the previous procedure and the painful stitches drawn on the scalp. (B) Radioscopy in profile showing the position of the electrodes from C4 to C1. (C) Intraoperative radioscopy in anterior-posterior view showing the position of the 16- electrode surgical lead.

As soon as there was correspondence between the area of pain and the stimulated area, we decided to place the generator at the same surgical time. Good pain control was achieved through a significant visual analogue scale reduction of $80 \%$ and withdrawal from the medications. The VAS score of 2 in the affected area may be related to the area stimulation itself.

The option for the dorsal cord stimulator between C1and C4 can allow adequate central control in these cases of refractory occipital neuralgia. It allows greater covering area by the stimulation and more programs possibilities in the followup control. Another advantage of dorsal cord stimulation at this level is the anatomical characteristic of the cervical plexus

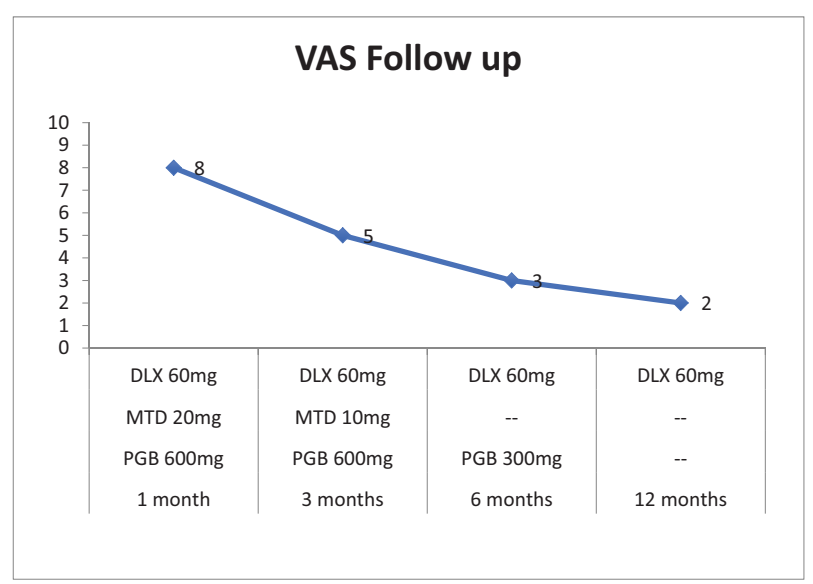

Fig. 2 Visual analogue scale follow-up after spinal cord stimulation. Visual analogue scale versus medication 1, 3, 6 and 12 months after surgery. Abbreviations: DLX, duloxetine; MTD, methadone; PGB, pregabalin; VAS, visual analogue scale. and the occipital nerves with numerous anastomoses as well as the possibility of activation of adjacent cervical spinal areas and trigeminal nuclei. ${ }^{1,4}$ The greatest negative point of the technique presented is the port site of the surgery; the procedure should be performed by a neurosurgeon with knowledge of the anatomy of the occipital and cervical regions. The postoperative period was well-tolerated by our patient, with a good pain control outcome.

Spinal cord stimulation between the $\mathrm{C} 1$ and $\mathrm{C} 4$ cervical segments can be an option for selected cases of refractory occipital neuralgia, including those patients who have already been submitted to neurectomy or rhizotomy.

\section{Conflicts of Interest}

The authors have no conflicts of interest to disclose regarding the publication of this paper.

\section{References}

1 Choi I, Jeon SR. Neuralgias of the Head: Occipital Neuralgia. J Korean Med Sci 2016;31(04):479-488

2 Harden RN, Cottrill J, Gagnon CM, et al. Botulinum toxin a in the treatment of chronic tension-type headache with cervical myofascial trigger points: a randomized, double-blind, placebo-controlled pilot study. Headache 2009;49(05):732-743

3 Huang JH, Galvagno SM Jr, Hameed M, et al. Occipital nerve pulsed radiofrequency treatment: a multi-center study evaluating predictors of outcome. Pain Med 2012;13(04):489-497

4 Ducic I, Hartmann EC, Larson EE. Indications and outcomes for surgical treatment of patients with chronic migraine headaches caused by occipital neuralgia. Plast Reconstr Surg 2009;123(05):1453-1461

5 Rodrigo-Royo MD, Azcona JM, Quero J, Lorente MC, Acín P, Azcona J. Peripheral neurostimulation in the management of cervicogenic headache: four case reports. Neuromodulation 2005;8(04):241-248 